Annales Missiologici Posnanienses t. 20 (2015), s. 9-25

DOI: $10.14746 / \mathrm{amp} .2015 .20 .1$

ANDRZEJ ŁUKASZYK

Fundacja Redemptoris Missio / Redemptoris Missio Foundation

\title{
Wanda Maria Błeńska And Her Contribution To Fight Against Leprosy In The World
}

Wanda Błeńska was born on $30^{\text {th }}$ October 1911 in Poznan, Poland. She attended primary school in Poznan and completed secondary school in Torun (1928). Then she studied medicine at the University of Poznan (1928-1934). During her studies, she was deeply engaged in the activities of academic missionary circles. She served in the administration of these circles and as editor of Annales Missiologicae (Andrzejak, U początków 1-245). As a young physician she worked briefly in the city hospital in Torun and later in the Torun section of the State Institute of Hygiene. She also completed a six-month course in serology and microbiology in the same Institute in Warsaw, where she specialized in this field of medicine. In 1939, at the outbreak of World War II, Dr. Błeńska was working as a physician in the Polish Navy Hospital in Gdynia.

During the German Nazi occupation of Poland Dr. Błeńska returned to the Hygiene Institute in Torun but was allowed to work there only as a technician. At time of the war, beginning $13^{\text {th }}$ October 1942 , she was an active member of the underground Polish Home Army, reaching the rank of a 2nd Lieutenant, responsible for training of personnel in sanitary services and medical supplies. She acted under the pseudonyms Szarotka (edelweiss) and Grażyna. In June 1944 she was arrested by the Gestapo and imprisoned in Torun and then in Gdansk.

After the war, in 1945 she headed the city hospital in Torun but circumstances obliged her to move to Gdansk where she worked in the State Institute of Hygiene, lectured in the medical school and taught courses for nurses. In 1946, upon learning that her brother, a former prisoner of war who remained in Germany, was seriously ill, she applied for permission to visit him, but her application was refused. Dr. Błeńska did manage, however, to go to Germany 
in the coal box of a ship leaving from Poland. After helping her brother, it was impossible to return to Poland. So, she joined the woman's auxiliary service in General Maczek's First Polish Armoured Division, which was then stationed in Germany. She worked in Polish military hospitals in Germany and in Great Britain. She continued her studies on tropical medicine to fulfil her dreams to work as a missionary doctor and then decided to go to Africa. She studied tropical medicine in Germany (at the Nocht Institut fuer Schiffe und Tropenkrankheiten in Hamburg, 1947), in England (at the University of Liverpool, 1948), and then continued her education in Africa.

Dr. Błeńska arrived in Uganda in 1950 and initially worked in the hospital of the Catholic mission in Fort Portal. In 1951 she became the medical director (the title was "medical superintendent") of the leprosarium in Buluba-Nyenga. She headed this institution for 32 years, and for a period of ten years thereafter trained physicians, students and paramedical personnel, in addition to working as a medical consultant. She returned to Poznan, Poland, in 1993, but in 1994 she attended the celebration of the $60^{\text {th }}$ anniversary of the Buluba and this was her last official visit there. During the celebration, Dr. J. Kawuma, Dr. Błeńska's Ugandan successor, emphasized that the health care system for lepers developed during her time in Buluba reduced incidents of leprosy in the district from 20,000 to between 200 and 300 .

When Dr. Błeńska came to Buluba it was a small leprosarium near Lake Victoria, established in 1934 and conducted under very difficult conditions by Franciscan Missionary Sisters, managed by Mother M. Kevin Kearney. When she left in 1993, however, Buluba was an important and internationally-known centre for treatment, training and research, cooperating with leprosy centres in India and South America, research institutes in London, Amsterdam and Borstel, and with the World Health Organization. Over the years the Missionary Sisters greatly assisted the victims of leprosy by helping them to recover their identity as persons and integrating them into a community. The Sisters created living conditions for the patients in the form of an African village: accommodation, places for personal, private enterprise and social activity. They integrated patients into interest groups in occupational therapy, choral singing, dancing and sport, depending on individuals' abilities.

A history of Buluba, published by the Franciscan Missionary Sisters in 1984, states: "The year 1951 opened a new era for Buluba with the arrival of Dr. Wanda Błeńska, a Polish doctor, who having ... specialised in tropical medicine in England and came to Buluba in April, 1951 - the first permanent resident doctor. Still active in Buluba, and with her years of experience, she is now a Leprologist of international repute." (Buluba 10-12).

Thus, 1951 can be accepted as the starting point for a transformation brought by new medical, surgical and pharmacological techniques and discov- 
eries, as well as the modern approach to leprosy management and cure, which differed greatly from the traditional approach.

As early as in the fifties the governmental leprologist Dr. K. Braun decided to set up a network of small outstations in Uganda for initial segregation in diagnosis and control of the treatment of leprosy, points of so-called field work. Moreover, in 1956 a training programme for the education of leprosy assistants was begun. With the years this program progressed as candidates came to Buluba from all of Uganda's districts but also from neighbouring countries as Kenya, Sudan and Tanzania. In this way the auxiliary medical staff for the dispersed outstations could be educated. Government subsidies allowed the renovation of buildings in Buluba so that a permanent school block could be built for 300 children. The celebration of the silver jubilee in 1959 brought feelings of stability and plans for further expansion in the next decade. The plans, announced as a second spring in Buluba, included: (1) the expansion of the hospital building and laboratories to permit true conditions for research, (2) the reorganization of existing units for rehabilitation, physiotherapy, occupational therapy and social activities for integrating patients, (3) the maintenance of established leprosy treatment centres and the provision of additional centres in an accordance with The World Health Organization policy and local medical requirements, (4) primary health care with a view to leprosy control, and (5) educational indoctrination of people about leprosy.

The accomplishment of the plans was made possible in 1963 when the African representative of the German Leprosy Relief Association in Wurzburg arrived in Buluba and recommended the centre to the director of the Association for financial support. In 1965, The Mother Kevin Hospital, a new and modern building including supporting sections and laboratories, was opened for both leprosy and other patients. From this moment the hospital's long- or short-term treatment and retreatment of leprosy patients from Buluba and the dispersed outstations became much more accessible. By the end of the 1960s the number of the treatment outstations increased to 49 (with approximately 15,000 registered patients) supervised by medical doctors and nurses from Buluba. At the same time, the Mother Kevin Hospital also provided surgical and non-surgical help to other patients. A panoply of health services has been gradually completed thanks to the efforts of staff, local authorities and sponsors. New buildings were constructed for the laboratory, various rehabilitation branches, a pharmacy, for staff housing and a training school, and the specialized professional equipment procured for laboratory and X-ray diagnosis, physiotherapy, hydrotherapy, orthopaedics, production of prosthetic appliances. Buluba's history pointed out that "With the arrival, in 1964, of the late Miss Janina Bartwiecz [sic: Bartkiewicz], a Polish physiotherapist, this important sector of the work was firmly established" (Buluba 18). In the 1960s, 
moreover, occupational therapy and social activities integrating patients into the community were extended.

The fruitful effects became evident several years later. In the 1980s the anti-leprosy system was greatly consolidated. At that time Buluba represented the central referral and teaching hospital supervising treatment centres, leprosy villages and aid posts. The hospital provided medical aid to hospitalised patients and out-patients, and participated in many other activities such as education, training, various form of rehabilitation, physiotherapy and diversional therapy. Students from Makarere Medical School took part in courses on leprosy and tropical medicine, and postgraduates from Uganda and abroad completed special medical practice there. The hospital organized on-going courses for medical assistants, nurses, health visitors, physiotherapists and other health workers. The hospital rehabilitation programme included: counselling, health education, social welfare and activities integrating patients. It also provided practical skills, such as carpentry, tailoring or shoemaking, and making orthopaedic appliances or prostheses. There were also various form of physiotherapy for individuals and groups. This system and specialized treatment procedures represented an approach in the fight against leprosy, which was not common medical practice. As it was expressed in the Buluba history: "Field work has grown steadily over the past fifty years. [...] Segregation of patients is no longer necessary" (Buluba 30). Thus, Buluba's history gives hope that people may realize that leprosy is not as contagious as formerly thought and, therefore, segregation of patients is unnecessary. Effective therapy requires early diagnosis and treatment but, if applied, patients may be allowed to maintain normal patterns of life and the deformations and mutilations associated with this disease may be prevented. So, to summarize the achievements of the leprosy centre, it is useful to recall the goals set and pursued at Buluba: HeaLING, Training, Research (Buluba 30).

Dr. Błeńska was deeply engaged in all areas of the centre: in medical diagnosis and treatment, training and education, and research. Her Polish coworkers enriched her work most especially in the area of the treatment of patients, physiotherapy and training. As was mentioned in the history of Buluba "The Leprosy Advisers: Dr. Henryk Novak and Dr. Wanda Marczewska and the Leprosy Control Officer, Sister Mary Ryan, O.S.F. moved their quarters to Buluba. This resulted in a general pooling of knowledge and resources, and the initiation of a new training programme" (Buluba 27, 29).

Her team conducted extensive medical diagnosis and treatment in the $\mathrm{Bu}-$ luba hospital and in the out-stations. Dr. Błeńska indicated (Błeńska, Leprosy) that an effective fight against leprosy must go in two directions: treatment and prevention. She did everything she could in this respect. She extended and improved the techniques of diagnosis and treatment in her leprosy centre, and she 
also modified laboratory conditions. Her vacations in Poland were dedicated to learning about the surgeries and rehabilitation techniques recently developed in the Poznan medical school's clinics of surgery, orthopaedics, rehabilitation, ophthalmology and others, and histological techniques in the pathomorphology department of Pomerania's medical school. She then brought this knowledge and the skills gained to the African context to help her patients and to introduce techniques of modern diagnosis and histology. Because of the numerous medical stations spread widely in Uganda and other African countries she made medical care available to a greater number of lepers for early diagnosis and control of treatment. This favoured prevention and reduced the number of leprosy incidents, thus preventing possible epidemics. To improve the effects of pharmacological therapy, she progressively applied the drugs available and introduced the multi-drug therapy indicated by the World Health Organization. In her lecture (Błeńska, Leprosy) she mentioned a list of drugs for the specific treatment of leprosis: the oldest, Diaminodephenylsulphone (D.D.S.), and Thiosemicarbasone, Rimifon, Vadrine, Etisul, Thiambutosine (D.P.T.), Riminophenasine (B 663) as well as adjuvant drugs such as corticosteroids, vitamins and so on. She also mentioned that leprosy sufferers, often deprived of human dignity, needed not only proper medical treatment but also the sympathy and the spiritual help available from a missionary hospital because hope in being restored to community is helpful in treatment.

The work of Dr. Błeńska also strongly supported the educational program of the Buluba leprosy centre. She took part in the education of university students and postgraduate fellows specializing in tropical medicine, improving skills in diagnosis and healing the lepers, or carrying out research recommended by the World Health Organization. In 1957 she was appointed a lecturer at the Makarere University Medical School in Kampala, and in 1967 the Board of Makarere College distinguished her with the title Honorary Lecturer in the Department of Medicine. First and foremost, however, she focused her activity on teaching and training to prepare medical staff for combating leprosy in Uganda and other African countries. In 1956, jointly with the Franciscan Sisters, she founded the Leprosy Assistants Training School in Buluba which continued in operation up to 1982. She delivered lectures there on tropical medicine, treatment of leprosy patients, first aid in emergencies and nursing. Students attended the school for two years and could complete their studies by taking the state exam. Dr. Błeńska lectured also in nursing schools located in five other places in Uganda. Moreover, she also delivered lectures on leprosy during medical advancement courses, lasting from one to four weeks, which were frequently organized in Buluba by the World Health Organization or the Ugandan Ministry of Health for clinical doctors specialized in different kinds of medical sciences. Finally, it must be mentioned that beginning in the 
1950s she continuously participated in lectures for teachers (tutors) of nursing schools and paramedical and nursing staff of various leprosy outstations in Uganda and Sudan. So, when Dr. Błeńska worked in Buluba it was recognized as an important leprosy centre. In 1993, a part of the Buluba leprosy centre which focused attention on teaching and training was officially named the Wanda Błeńska Training Centre.

It is important to mention that Dr. Błeńska felt the need to increase greatly the number of Ugandan inhabitants working in and managing the treatment and cure of leprosy and the entire health service in this and other African countries. In her lecture given at Makarere University (Błeńska, Leprosy) she said: "I am deeply convinced that by having a Ugandan leprologist, born and educated in this country, who could better understand and be accepted by the people, many of our problems could be solved." Therefore, she was happy in 1982 to hand over the medical superintendent post of the Buluba leprosy centre to a Ugandan leprologist, Dr. Josef Kawuma.

As to research, the following interesting notation can be find in the history of Buluba:

From 1956 onwards Dr. Błeńska was deeply involved in the matter of research. Buluba co-operated in scientific research with the Medical Research Council, Mill Hill, London, in immunological investigations and preparation of possible anti-leprosy vaccines. In the 1967/71 period treatment trials with B8663/Lamprene was carried out in conjunction with Research Centre in Amsterdam, and in 1971/74 with the Research Institute, Borstel, Germany, introducing multi-drug treatment: Rafampicin, Isoprodian and long-acting Sulphonamide (Buluba 18).

Dr. Błeńska was recognized as a leprologist of international reputation and invited to take part in the investigation of the immunological aspects of leprosy and anti-leprosy vaccines as well as on effective multi-drug treatment procedures, in concert with leading centres of leprosy research in Europe. The effects of the investigations among others led to the directive issued by the World Health Organization that multi-drug procedures should be applied in leprosy treatment.

Dr. Błeńska participated in numerous international congresses, taught in several schools in Africa and in Europe, incorporated the majority of her observations and research into World Health Organization reports and published some of her results in scholarly journals (Błeńska, Pattern of leprosy). Some of her publications are indicated in the list annexed to this article. She presented the results of her observations on treatment of leprosy patients at the congress in Madrid (1953) and in a lecture, "Pattern of leprosy reactions in Uganda," during the International Leprosy Colloquium in Borstel (1970) and 
another lecture, "Drug treatment of reactions in leprosy," at the leprosy conference in Dar-es-Salaam, Limuru $(1973,1974)$. She also participated actively in the congresses of leprologists in Mexico, Hague, New Delhi, Bergen, London and others.

Dr. Błeńska also acted as member or associate member of recognized scientific or professional associations, such as the Royal Society of Tropical Medicine, London (beginning in 1948), the International Leprosy Association (USA), the East African Leprosy Association, the Association of Physicians of East Africa, Nairobi, and the Association of Surgeons of East Africa.

Dr. Błeńska worked in Africa but also visited India for diagnosis and treatment of lepers at the Father Marian Żelazek's leprosarium in Puri (6 months, 1986/1987) and at Mother Theresa's home in Calcutta. She often visited hospitals and teaching institutions in Poland and other European countries in order to consult the tropical medicine departments or to convey her views, knowledge and experience to persons planning to work at missions in tropical areas.

We can now say that Dr. Błeńska contributed much to the strategy of fight against leprosy in the world. She contributed significantly in transforming the handling of the immense, and still unsolved, problems of human suffering due to leprosy. Her research and teaching, her work with patients, her leadership in establishing clinics for treatment and cure, her courage and perseverance in overcoming countless obstacles and, above all, her selfless devotion to the never-ending task of relieving human suffering earned her international admiration and respect. The efforts of Dr. Błeńska and her team was considered work for humanity. ("Undaunted by danger" The Natal Witness 1967).

Her achievements are reflected in the many honours she received. For examples, she received the Medal Pro Ecclesia et Pontifice from Pope John XXIII in 1961, recognition from the Polish Government in Exile (1962 and 1978), the Sovereign Order of the Knights of Malta (1965 and 1987), the Bene Merenti in 1984 from Pope John Paul II, the Polish Government Order of Merit in 1985, the Commander's Cross of Polonia Restituta in 1993 from the Polish President Lech Walesa, the first K. Marcinkowski Medal in 1984 from the medical school in Poznan, and various honours from Uganda itself, including the Independency of Uganda medal in 1964 and citizenship held for life. In 1994 Dr. Błeńska received a doctorate honoris causa from the Karol Marcinkowski Academy of Medicine (now University of Medical Sciences) in Poznan. In 1996 Dr. Błeńska was honoured with the Alfred Jurzykowski Foundation Award (USA) in recognition of her outstanding contribution to the fight against leprosy in Africa and her selfless devotion to relieving human suffering.

Dr. Błeńska's fruitful and creative life has also been reflected in numerous press articles, documental movies and books. On the occasion of the bestowing of the doctor honoris causa, a commemorative volume devoted to 
Dr. Błeńska's life and work was published by the nominating medical school (Wanda Bteńska), including both commemorative contributions and scholarly articles (Andrzejak, Wanda Maria Błeńska; Błeńska, Pokochałam moja pracę; Król; Łukaszyk, Laudatio; Łukaszyk, "Matka trędowatych"; Pawłowski). Three other recent publications, in popular form, presenting her life and work in Africa, and a monograph were printed for the students of the Pontifical Faculty of Theology in Poznan (Andrzejak, U poczatków; Andrzejak, Wanda Maria Bleńska; Andrzejak i Różański; Florczak; Molewska i Pawelec; Nawrocka). In addition, some institutions, such as elementary schools in Poznan and Niepruszewo and the department of occupational diseases and toxicology of the Fr. Raszeja hospital in Poznan have been named after Dr. Błeńska.

After returning to Poznan in 1993 Dr. Błeńska continued her welfare, educational and inspirational work. She joined the founders and the council of the Fundatio Redemptoris Missio (acting since 1997 within an international system as a member-foundation of Medicus Mundi) which provides humanitarian aid not only to Uganda and African countries but to all countries of the Third World. She also participated with another foundation to raise funds to ransom girls and boys kept imprisoned and tortured by local gangs in northern Uganda and Sudan. She also lectured in the Missionary Formation Centre in Warsaw, participated in discussions in radio and TV, presented lectures during courses on tropical medicine in Poznan and other cities, and was invited by the medical school to lecture on medical ethics. These lectures were especially admired by young participants.

The Redemptoris Missio Foundation appreciated her immense contribution to its origin and its development and was most grateful for her continuous animation of its activities. She took part in its council and on its board, participated actively in the creation and realization of its programme, and heartily influenced the charitable work of young volunteers. She was also the most recognizable representative of the Foundation during official events and ceremonies. The founder, Professor Zbigniew Pawłowski, proclaimed her the Mother of Redemptoris Missio. Dr. Błeńska was always popular with the university and high school students who gathered to discuss charitable work for missions in poor countries. These events, organized by Redemptoris Missio and Poznan University's Department of Tropical Diseases, known as Meetings with Africa and her personal contacts with children from the school named for her are described in articles included in this volume of "Annales." In addition, she participated with various societies in Poznan. She felt especially honored to be connected to the Academic Missionary Circle as a guest during its meetings, discussions and ceremonies. On the occasion of her $100^{\text {th }}$ birthday, the Circle published a book on her fruitful life (Molewska i Pawelec) and also arranged an evening celebration on Jordan bridge at the Warta River. Dr. Błeńska had 
been frequently invited by authorities of the city, university and other organizations to take part in formal events. She also participated in meetings of the veterans of the underground Polish Home Army.

Even at the end of her life Dr. Błeńska did not discontinue her services for others. Being close to 100 years old she was still being invited to express her feelings, experiences and advice to young volunteers working for health service centres in the missions. Not to be forgotten were her meetings with students, young girls and boys, on her $102^{\text {nd }}$ birthday. She spoke as she typically did in an acknowledgement in response to the A. Jurzykowski Foundation Award (USA):

[...] the time when I have been helping the sick by the work of my hands is gone and I am very happy continuing to alleviate their suffering by the hands of other dedicated persons with generous help of your award. The whole my life and its professional realization was in keeping with my living vocation that up to now is for me a guide in taking decisions and, therefore, I accept with an enthusiasm the honorary site of the award but the monetary grant of it I design to support foundations of humanitarian aid [...]. [original statements of W. Błeńska, from a personal letter]

She gave the entire sum to support two humanitarian foundations: (1) the Redemptoris Missio and (2) a foundation for children stricken with neoplastic sickness.

At that time, as earlier, Dr. Błeńska's activities for the Poznan community was acknowledged with a number of medals, titles and awards. In 2000 she was honored with the Order of the Smile, conferred by children. In 2001 she received the title Meritorious by the city of Poznan and the title Honorary Citizen of the city of Poznan. The Redemptoris Missio Foundation distinguished her with the "To Those Doing Right" medal (2001) and the title of Honorary Volunteer (2009). She also received the titles of Outstanding Individuality of Organic Work (2003), the Labor Omnia Vincit medal (2006) and the R. Kapuściński memorial award (2007). These acknowledgements were crowned by Cross of the Order of St. Sylvester conferred by John Paul II (2003) and the Grand Cross of Polonia Restituta Order (2011) conferred personally by President Bronisław Komorowski on the occasion of her $100^{\text {th }}$ birthday.

Dr. Błeńska held outstandingly high ethical standards and had a personality open and friendly to everybody. She was most honest and religious, a very self-effacing but active person, and altruistic. Her personality was extremely warm. So her students and co-workers used to say that it was a pleasure to be under the influence of her personality. Open and helpful to everybody, she was always extremely active in accordance with the maxim she put into her Sir 


\section{MIĘDZYNARODOWA KAPITUŁA ORDERU UŚMIECHU INTERNATIONAL CHAPTER OF THE ORDER OF SMILE}

PL 02-009 WARSZAWA, al. Niepodległości 235/237 m 10 Konto PKO BP XV O/WARSZAWA Nr 10201156-5630-270-1

Tel. Pryw. 629-63-81 Sekretarz Kapituły Orderu Uśmiechu

Warszawa, dnia 20.03.2000 r

Szan. Pani

\section{Błeńska Wanda}

\section{Szanowna Pani.}

W imieniu Międzynarodowej Kapituły Orderu Uśmiechu, mam zaszczyt zawiadomić, że na wniosek dzieci w dniu 29.02.2000 r. został przyznany Pani

Order Uśmiechu.

Składam serdeczne gratulacje w imieniu Kapituły Orderu Uśmiechu i własnym.
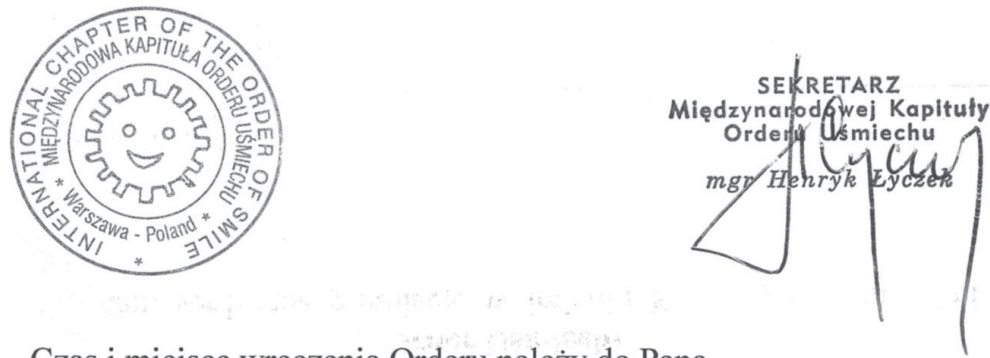

P.S. - Czas i miejsce wręczenia Orderu należy do Pana. 


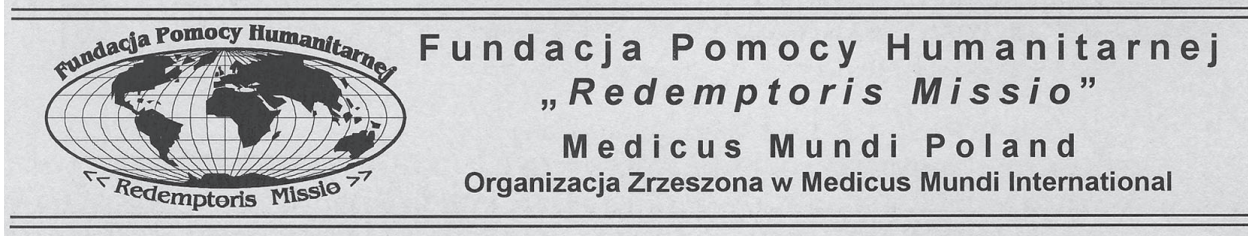

„Nikt z nas nie żyje tylko dla siebie..."

Zarząd i Rada

Fundacji Pomocy Humanitarnej «Redemptoris Missio»

przyznały

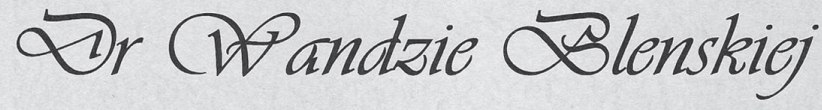

medal

„Tym, którzy czyniq dobro..."

za serce $i$ zaangażowanie

w niesieniu pomocy polskim misjonarzom

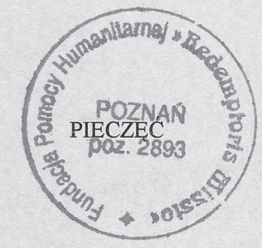

PRZEWODNICZACY RADY

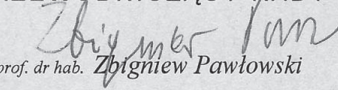

WICEPREZES FUNDACJI

Woiriech Ouscronal.
mgrlWojciech Owczarzak

Poznań, dn. 8 listopada 2001 roku 


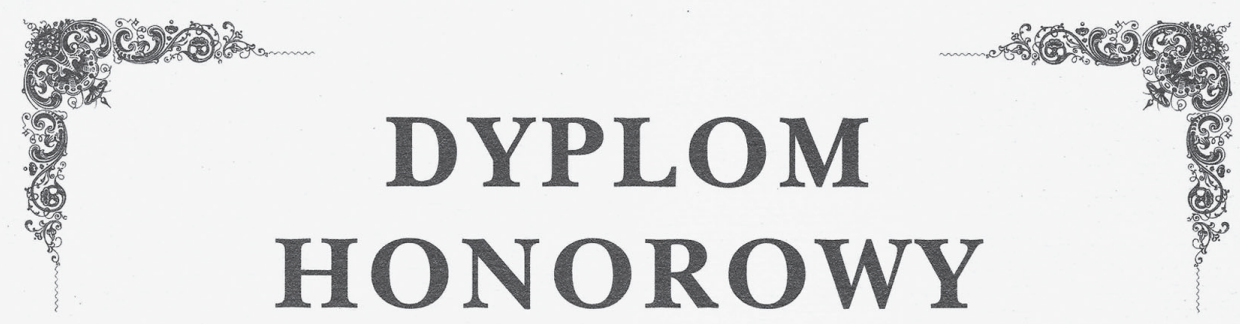

Towarzystwo im. Hipolita Cegielskiego

i

Kapituła „Złotego Hipolita”

uroczyście oświadczają, że

Pani

dr Wanda Błeńska

lekarz trędowatych w Afryce

otrzymuje godność

„Wybitnej Osobistości Pracy Organicznej”

oraz

statuetkę

„ZEOTEGO HIPOLITA"
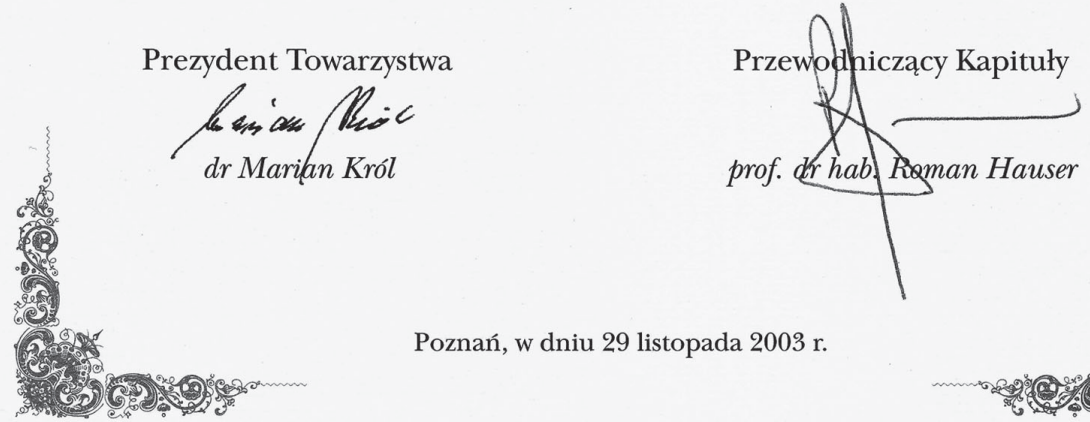

Poznań, w dniu 29 listopada 2003 r. 


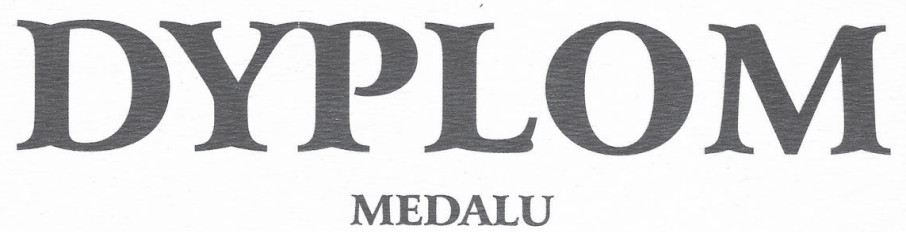

"PRO MEMORIA"

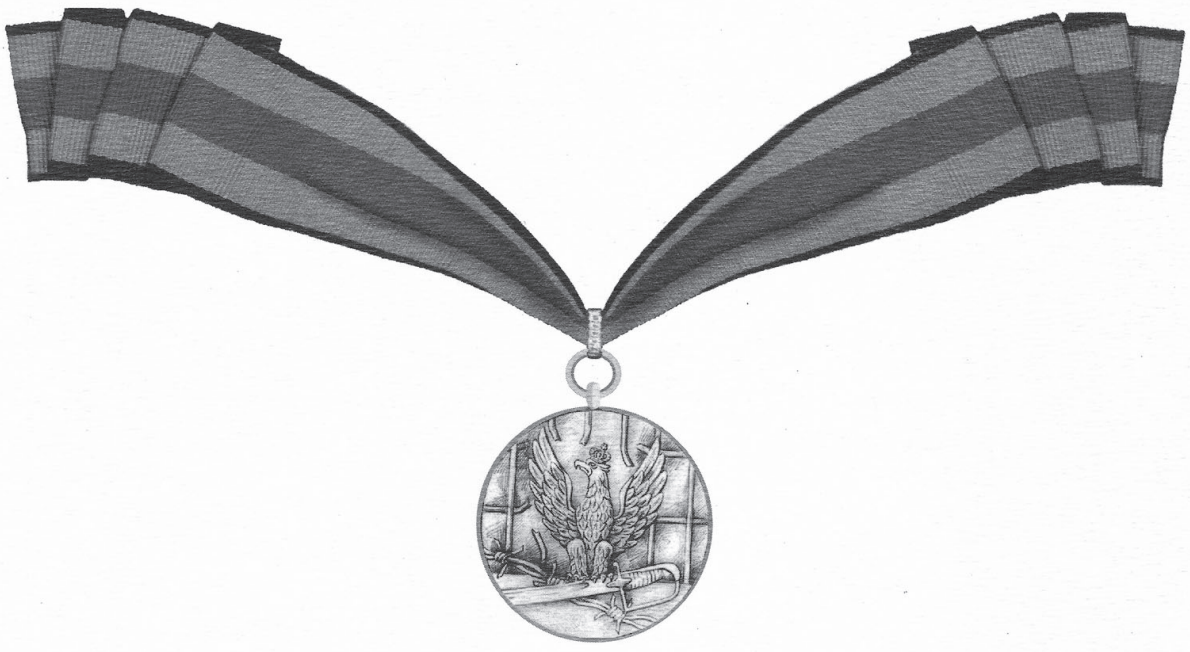

Decyzją Nr 1607/KU/10 wyróżniam

\section{Panią Wandę BŁEŃSKA}

\section{Medalem "PRO MEMORIA"}

za wybitne zasługi w utrwalaniu pamięci o ludziach i ich czynach w walce o niepodległość Polski podczas II wojny światowej i po jej zakończeniu

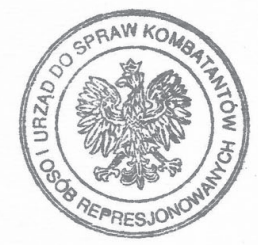
Urzędu do Spraw Kombatantów i Osób Repyesjonoynych



Jan Stanislaw Ciechanowski 


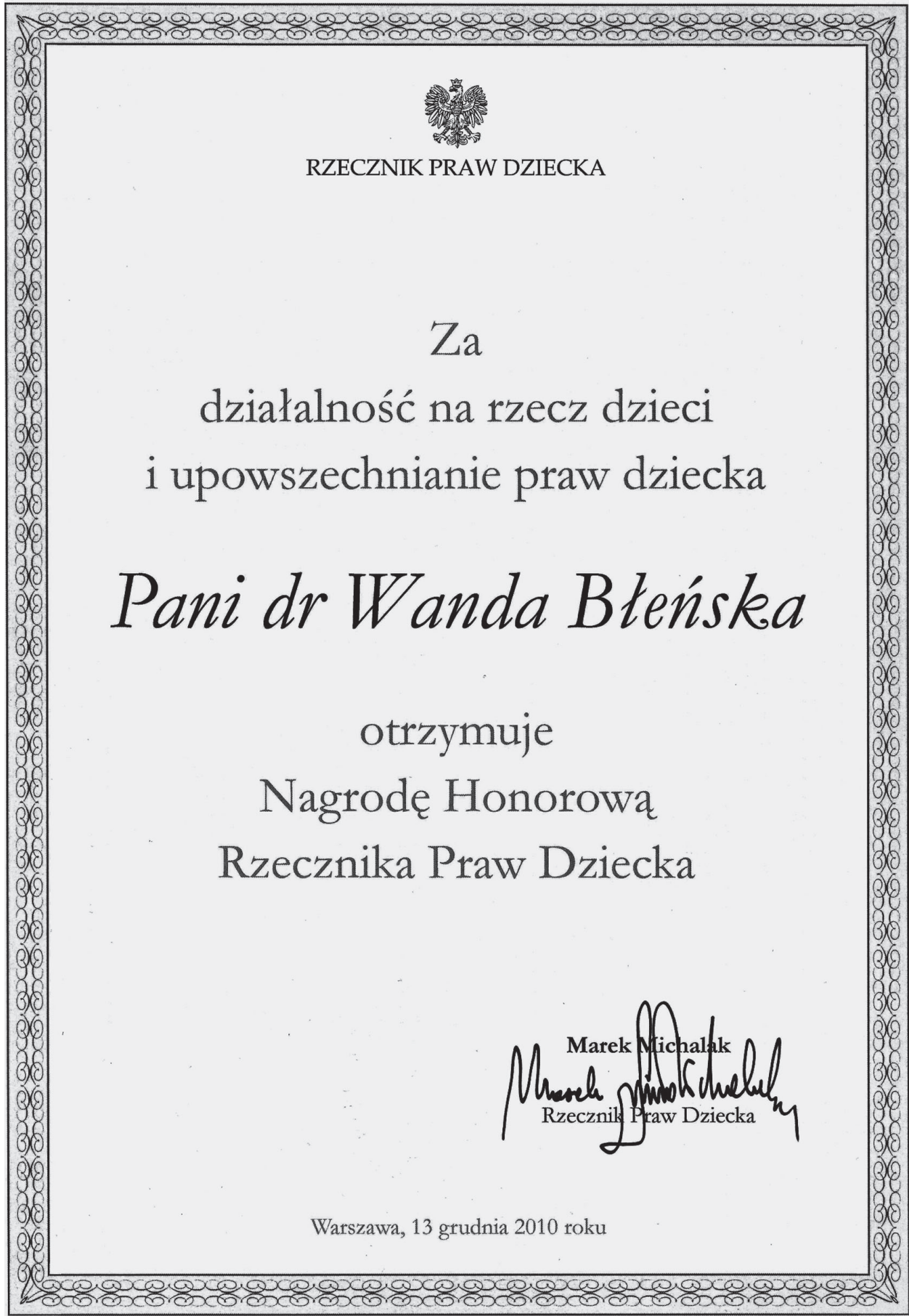


Albert Cook memorial lecture given at Makarere University (Błeńska, Leprosy): "In my ... daily struggle I feel uneasy remembering Sir Albert's favourite maxim - Christianity is not a creed to be learnt, but a life to be lived".

Dr. Błeńska was always true to the ideals of the Hippocratic Oath, the Christian commandment to love every one of our neighbours, and love of one's own Motherland. A profound religious sensitivity was always the background for her reason for living. She was a person influencing others, commonly acknowledged as a moral authority. May we hope that her life and her activities guide future generations.

\section{SUMMARY}

The article speaks about professional and social activities of Dr. Wanda Maria Błeńska (1911-2014), a high-minded person fully dedicated to medical help and humanitarian aid for the people in Africa and other countries of the world. Dr. Wanda Błeńska has begun her medical studies at the University of Poznań (1928-1934) and continued her education in Warsaw, Hamburg and Liverpool. In 1950 she arrived to Uganda and in 1951 she became the medical director of leprosy centre in BulubaNyenga. She headed this institution for 32 years and thereafter she continued to train physicians, students and medical personnel, in addition to functioning as a medical consultant. After returning to Poznan in 1993 she continued educational, organizational and social work.

Keywords: Wanda Blenska; medical studies, academic missionary movement; tropical medicine; Buluba (Uganda); leprosy in Africa

Slowa kluczowe: Wanda Błeńska; studia medyczne, akademicki ruch misyjny; medycyna tropikalna, Buluba (Uganda); trąd w Afryce

\section{APPENDIX}

\section{A selection of Wanda Błeńska's articles}

1. Błeńska, Wanda. "Mitologia Brahmanizmu, życie i obyczaje brąhminów. La mythologie du brahmanisme: vie et les moeurs." Annales Missiologicae. Roczniki Misjologiczne (1932/1933): 209-227.

2. Błeńska, Wanda. "Leprosy in children." East African Medical Journal 43 (1966): 533-535.

3. Błeńska, Wanda. "Pattern of leprosy reactions in Uganda." International Journal of Leprosy and Other Mycobacterial Diseases 39 (1971): 433-443.

4. Błeńska Wanda et al. "Bacteriological effect of Lamprene (clofazimine) in lepromatous leprosy (report of one year treatment of 44 patients with 100mg Lampre daily)." Leprosy Review 42 (1971): 125-130. 
5. Błeńska, Wanda. "The Witness of Lay woman engaged in medical missionary work in Africa." [Conférence International des OPM à Lyon, novembre 1972]. Agence Internationale FIDES, Roma, 18 Nov. 1972, No. 2470 -NF 632. 636-637.

6. “Temoignage de la Doctoresse W.M. Błeńska (Uganda).” Les Oeuvres Pontificales Missionaires. $150^{\mathrm{e}}$ anniversaire de l'oeuvre de la Propagation de la Foi. Sous le signe de la Collegialité Apostologique. International Missionary Conference, Lyon 9-12 Nov. 1972, 173-178.

7. Błeńska, Wanda. "Dr. G. Lomholt." The East African Leprosy Bulletin, 2 (1973): 38-39.

8. Błeńska, Wanda. "Drug treatment of reactions in Leprosy." EALA Conference, Limuru, 1973, 1-8 [see also position 11].

9. Błeńska, Wanda. Kołakowska Elżbieta. "A pilot study of leprosy treatment with a combination of various antyleprosy drugs. Preliminary report”. Zeitschrift für Tropenmedizin und Parasitologie 24 (1973): 26-31.

10. Błeńska, Wanda. "Eine Missionsarztin gibt Zeugnis." Die Katolischen Missionen 93 (1974): 10-13.

11. Błeńska, Wanda. "Drug treatment of reactions in Leprosy." The East African Leprosy Bulletin 3 (1974): 31-38.

12. Błeńska, Wanda. "Mechanisms of reactions in Leprosy." The East African Leprosy Bulletin, 3 (1974): 23-30.

13. Błeńska, Wanda. "Przedmowa." Zeszyty Misjologiczne Akademii Teologii Katolickiej 1.1 (1974): 13-14.

14. Błeńska, Wanda. "New invesigations in the treatment of leprosy." The East African Leprosy Bulletin 3 (1976): 3-9.

15. Błeńska, Wanda. "Lekarka na misjach daje świadectwo." Misjonarze polscy w świecie. Paryż: Nasza Rodzina 2 (1977): 214-218.

16. Błeńska, Wanda. "Przemówienie z okazji przyznania medalu im. Karola Marcinkowskiego." Biuletyn Informacyjny Akademii Medycznej im. Karola Marcinkowskiego w Poznaniu (1984) 9: 13-14.

17. Błeńska, Wanda. "Uganda. Świadectwa misjonarzy.” II Krajowy Kongres Misyjny, Częstochowa 16-18 października 1992. Warszawa 1994. 197-204.

18. Błeńska, Wanda. "Pokochałam moją pracę wśród trędowatych." Wanda Błeńska - Doctor honoris causa Akademii Medycznej im Karola Marcinkowskiego. Poznań 1994. 29-30.

19. Błeńska, Wanda. "Leprosy - yesterday, today and tomorrow." The third Sir Albert Cook Memorial Lecture given at Makarere Medical School, Kampala University, 31 October, 1968. 1-12.

20. Błeńska, Wanda. "Pokochałam moją pracę wśród trędowatych.” Miesięcznik Kościelny Archidiecezji Poznańskiej, 46 (1995): 22-23.

\section{Works Cited}

Andrzejak, Ambroży. U początków ruchu misyjnego w Polsce: Biskup Kazimierz Kowalski 1896-1972. Poznań: Św. Wojciecha 1993.

Andrzejak, Ambroży. "Wanda Maria Błeńska - szkic biograficzny." Wanda Błeńska-Doctor honoris causa Akademii Medycznej im Karola Marcinkowskiego. Poznań: Akademia Medyczna im. Karola Marcinkowskiego, 1994. 31-41.

Andrzejak, Ambroży. Różański, Jarosław. Medycyna i ewangelizacja. Rozmowy z Wanda Błeńską. Poznań: Papieski Wydział Teologiczny, 1996.

Błeńska, Wanda. "Pattern of leprosy reactions in Uganda". International Journal of Leprosy and Other Mycobacterial Diseases 39 (1971): 433-443. Dostęp 4.11.2015. <http://ila.ilsl.br/pdfs/ v39n2pt2a35.pdf $>$ 
Błeńska, Wanda. "Pokochałam moją pracę wśród trędowatych". Wanda Błeńska - Doctor Honoris causa Akademii Medycznej im Karola Marcinkowskiego. Poznań: Akademia Medyczna im. Karola Marcinkowskiego, 1994. 29-30.

Błeńska, Wanda. "Leprosy - yesterday, today and tomorrow. The third Sir Albert Cook Memorial Lecture given at Makarere Medical School on October 31, 1968." Wanda Bteńska - Doctor honoris causa Akademii Medycznej im Karola Marcinkowskiego. Poznań: Akademia Medyczna im. Karola Marcinkowskiego, 1994. 44-56.

Buluba 50 years. Buluba: St. Francis Leprosy Centre, 1984.

Florczak, Zofia. Dokta. Oborniki Wielkopolskie: Missio Press, 1993.

Król, Jerzy. "Ocena działalności dr Wandy Błeńskiej w związku z wnioskiem o nadanie tytułu Doctor Honoris causa." Wanda Błeńska - Doctor honoris causa Akademii Medycznej im Karola Marcinkowskiego. Poznań: Akademia Medyczna im. Karola Marcinkowskiego, 1994. 22-25.

Łukaszyk, Andrzej. "Laudatio." Wanda Bteńska-Doctor honoris causa Akademii Medycznej im Karola Marcinkowskiego. Poznań: Akademia Medyczna im. Karola Marcinkowskiego, 1994. 18-21.

Łukaszyk, Andrzej. "Matka trędowatych". AM na bieżąco. Pismo Akademii Medycznej im. Karola Marcinkowskiego w Poznaniu. 14 (1994): 1-2.

Molewska, Joanna. Pawelec, Marta. Wanda Błeńska. Spetnione życie. Poznań: Święty Wojciech, 2011.

Nawrocka, Małgorzata. Jej światło. O życiu i dziele Wandy Bteńskiej. Poznań: Wydawnictwo Kontekst, 2005.

Pawłowski, Zbigniew. “Dr Wanda Błeńska - Matka fundacji „Redemptoris Missio.” Wanda Błeńska - Doctor honoris causa Akademii Medycznej im Karola Marcinkowskiego. Poznań: Akademia Medyczna im. Karola Marcinkowskiego, 1994. 42-43.

„Undaunted by danger, these women work for humanity”. The Natal Witness, 25 August 1967: 10.

Wanda Błeńska - Doctor honoris causa Akademii Medycznej im Karola Marcinkowskiego. Poznań: Akademia Medyczna im. Karola Marcinkowskiego, 1994.

Professor Andrzej Lukaszyk, MD, PhD, histologist, embryologist; professor emeritus of Poznan University of Medical Sciences; council member of the Redemptoris Missio Foundation; in 1994 conferring the honorary doctor title of the Poznan University of Medical Sciences on Wanda Błeńska. 




